\title{
Rafał Kowalski
}

\author{
Pontifical Faculty of Theology in Wrocław
}

\section{Using the five-milestone formula in the process of preparing homilies and sermons}

\section{Zastosowanie formuły $5 \mathrm{~K}$ w procesie przygotowania homilii}

\begin{abstract}
The text concerns the possibilities and methods of using the five-milestone formula for persuasive public speaking developed by Lidia Buksak, a persuasive speaking coach, in the process of preparing homilies and sermons.

The author - having in mind the context of theological science - discusses particular preparation stages that make an appealing and effective speech which will influence the thoughts and actions of the audience. In the process the author brings to light these elements which may contribute to improving the quality of homilies. The reader's attention

is drawn to the four milestones or stops on

the circumference of the circle which are to guide the reader on the road towards an effective message. The questions relevant to these four milestones concern the objective of a speech, the person of a speaker, the profile of an audience and the benefits for the listeners.

The fifth, and the last one, of the milestones is the message itself. Without prejudice to the position of the Church on the contents which should be included in a homily, the author indicates how to use the output of communication science for homiletic purposes, which will result in ensuring the appropriate organisation of a message, being, in this case, a piece of homiletic speech.
\end{abstract}

KEYWORDS: preaching the word of God, preparing homilies, homily as a persuasive text, the language of homilies, evangelisation

\begin{abstract}
ABSTRAKT
Tekst traktuje o możliwości i sposobach wykorzystania formuły $5 \mathrm{~K}$, stworzonej dla potrzeb wystąpień perswazyjnych przez trenera wystąpień publicznych Lidię Buksak, w procesie przygotowania homilii i kazań. Autor, zachowując kontekst nauk teologicznych, omawia poszczególne etapy, prowadzące do stworzenia atrakcyjnej i skutecznej mowy, która będzie oddziaływała na myślenie i działanie słuchaczy. Wydobywa przy tym te elementy, które mogą przyczynić się do poprawienia jakości homilii. Czytelnik zatrzymuje się przy czterech „przystankach” koła struktury, które mają go doprowadzić do przygotowania skutecznego komunikatu, a którym odpowiadają pytania: o cel przemówienia, o to kim jest mówca, jacy są jego słuchacze i jakich korzyści oczekują po wysłuchaniu mowy. Ostatnim (piątym K) jest sam komunikat. Nie naruszając nauczania Kościoła na temat treści, która powinna znaleźć się w homilii, autor wskazuje, jak wykorzystać osiągnięcia nauk o komunikacji dla celów homiletycznych, czego efektem będzie nadanie właściwej struktury komunikatowi, którym w tym przypadku jest jednostka przepowiadania.
\end{abstract}

\section{SŁOWA KLUCZOWE:}

głoszenie słowa Bożego, przygotowanie homilii, homilia jako tekst perswazyjny, język homilii, ewangelizacja 


\section{INTRODUCTION}

A theme that has recently been recurring very often in Church documents on the preaching of the word of God is to prepare the preacher for his ministry. Benedict $\mathrm{XVI}$ calls us to take this issue seriously, defining it as an indispensable condition for improving the quality of evangelization in the modern world. ${ }^{1}$ Francis, in turn, develops this idea by saying that "preparation for preaching is so important a task that a prolonged time of study, prayer, reflection and pastoral creativity should be devoted to it." ${ }^{2}$ He proposes very concrete steps leading to the creation of a text to be preached from the pulpit, while warning against superficial treatment of this process. These thoughts have also been reflected in the Homiletic Directory. The aim of the Directory is to help the homilists to prepare the texts that they will be giving to the faithful gathered at the Eucharist. ${ }^{3}$

The above statements are guided by the thought that although the effectiveness of preaching in the Church is conditioned by the action of the Holy Spirit and as for the substance homilies are the word of God, they remain the work of a preacher. ${ }^{4}$ As such, they require the ministers of the Word to take into account not only theological rules, but also everything that can facilitate the transmission of the message and improve its effectiveness. It is the responsibility of the preacher not only to convey the content in accordance with the Church's teaching, but also to take care of the attractiveness of the message so that his efforts can properly render the Word he preaches. ${ }^{5}$ In this context, it seems necessary to take

${ }^{1}$ Benedict XVI, Post-Synodal Apostolic Exhortation Sacramentum Caritatis (hereinafter: SC) 46.

${ }^{2}$ Francis, Apostolic Exhortation of Evangelii Gaudium. On the proclamation of the Gospel in the modern world (hereinafter: EG) 145.

${ }^{3}$ Congregation for Divine Worship and Discipline of the Sacraments, Homiletic Directory (hereinafter: DH) 1.

${ }^{4}$ See K. Panuś, Sztuka głoszenia kazań [The art of preaching], Kraków 2008, p. 13; cf. W. Broński, Język i zachowania niewerbalne kaznodziei w służbie nowej ewangelizacji [The language and non-verbal behaviours of preachers at the service of the new evangelization], "Przegląd Homiletyczny" 2005(9), p. 126.

${ }^{5}$ Congregation for the Clergy, The Priest, Pastor and Leader of the Parish Community; cf. S. Dyk, Atrakcyjny sposób przepowiadania homilijnego [Attractive way of homily preaching], in: H. Słotwińska (ed.), W służbie Bogu i ludziom. Księga pamiątkowa poświęcona ks. prof. dr. hab. Władysławowi Głowie z okazji 65-lecia urodzin i 40-lecia kapłaństwa [In service to God and people. Memorial Book dedicated to Rev. Prof. Władysław Głowa on the occasion of his 65th birthday and 40th anniversary of the priesthood], Lublin 2005, p. 133-142. 
note of the encouragement of the Fathers of the Second Vatican Council who, in their search for a better way to convey Christian doctrine, recommended the application not only of the principles of theology but also of the achievements of the secular sciences, especially psychology and sociology. ${ }^{6}$
Although the effectiveness of preaching in the Church is conditioned by the action of the Holy Spirit and as for the substance homilies are the word of God, they remain the work of a preacher.

This opens the way to the considerations we are undertaking in this paper. Keeping in mind the theological aspect of the nature of the homily, we want to point out how one of the formulas presented in the field of communication sciences may help in preparing the proclamation of the word of God. That is because we assume that the methods developed in the field of these sciences that facilitate the process of preparing and improving the effectiveness of persuasive speeches can, after slight corrections, be used in the process of preparing homily, thereby improving its power to influence listeners. It will also justify the thesis concerning the need to intensify education in the field of communication science of theology students preparing to preach the word of God.

\section{THE CIRCLE OF THE PRESENTATION STRUCTURE AS A PART OF THE PREACHER'S PREPARATION}

From a communicative point of view, the homily can be treated as a public persuasive statement. The aim of the homily is not to convey information, but to

${ }^{6}$ Vatican Council II, Pastoral Constitution on the Church in the Modern World (hereafter: PCC) 62. Cf. Congregation for the Clergy, General Directory for Catechesis 32. Cf. Paul VI, Encyclical Ecclesiam suam (hereafter: ES) 91: the Pope points out the need to return to the true art of preaching the word of God. He suggests looking for ways to make preaching strong, transparent, serious, and to make it possible for the preacher to match "in noble competition" those who, through the art of eloquence, have influence over believers. 
proclaim the works of God in such a way as to make the recipient act in a concrete way. This will be a response given to God's presence and action. In the liturgical context, this response will express a deeper experience of the Eucharist. In the extra-liturgical context - a life according to the Gospel. This has been pointed out by the authors of the mentioned Homiletic Directory, where they emphasize that the homily is to prepare the community to celebrate Mass and to recognize that in the Eucharist they participate in the mystery of Jesus' death and resurrection; it is also to suggest how people participating in the sacramental life can bring the Gospel values into the modern world and their everyday life. ${ }^{7}$ It therefore seems appropriate for homiletics to adopt one of the methods of preparing a persuasive presentation: the five-steps formula.

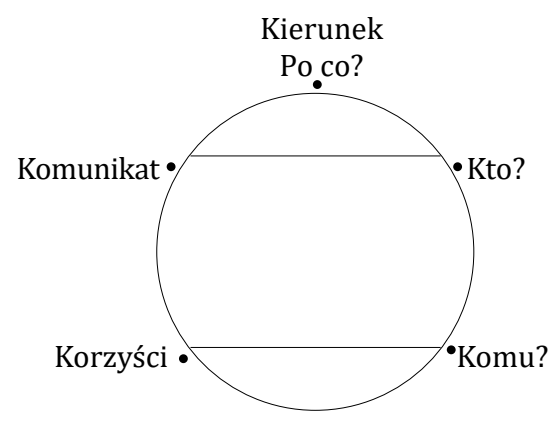

This method was created and proposed by Lidia Buksak and is based on the so-called presentation structure circle. The mentioned five-milestone formula is made up of 5 stages of persuasive speech preparation. The points stand for: "direction," "who?" "who?" "benefits" and "message."8 The speaker - and in our case the homilist - starting to prepare the text of his speech should take care of creating the mentioned circle and then analyse the situation by answering the questions corresponding to the particular points or stages, which we will also call stops for our consideration. Before the preacher reaches the point where he will work on the text of the homily, he must stop, according to the structure's circle, at four places, gathering the necessary information.

\section{DIRECTION, OR WHAT ARE WE PREACHING FOR?}

When preparing a homily, the preacher is faced with the need to outline its thematic area and then verbalize the main message, often referred to as the main 
motif or simply the subject. Theorists of social communication have no doubt that a good test to check the level of preparation of a speaker is to pose a question: "What will you talk about?" If he can answer in one sentence, it can be assumed that the speech will be coherent and concrete. Inability to give an answer or trying to describe it in many words may suggest that the speech will be chaotic, consisting of a lot of detached information, which will soon disappear from the listener's memory. ${ }^{9}$

Setting a topic is not enough. The speaker should at the same time define the goal he wants to achieve by making a speech. Following this line of reasoning, it should be stated that each unit of preaching should be built around a single thought; the preacher has the obligation to specify the expected results. Most often this will be expressed in the form of a description of the reactions desired in connection with the word heard. Given the specificity of this form of preaching the word of God, which is a homily, the goals described by words like "I want to inform you about..." or "I will explain to the participants of the Eucharist that..." should be considered insufficient. Explanation is, as Chino Biscontin remarks, one of the means at the homilist's disposal with which he strives after the desired goal. Yet, stopping at the level of the desire to explain is to confuse the means with the end and leads to one of the most common mistakes, called didacticism. The effect is that such a homily is full of doctrinal explanations, leaving the listener with no answer to the question: "what does it matter to me?" It is therefore appropriate that, when the preacher prepares a text of his preaching, he should outline the attitudes or actions which he wants to evoke in his listeners or which they should take after listening to the prepared text. It may be helpful at this stage to answer the question: "what do I want to provoke in those who will listen to me"? ${ }^{10}$

This style of work on the homily will make it possible to set out the most important points of the homily, to determine the information that the preacher intends to provide and to choose the appropriate structure, and will make it clear to those present at the Eucharist what the word of God they have heard

${ }^{9}$ A. Rzędowska and J. Rzędowski, Mówca doskonały. Wystąienia publiczne $w$ praktyce [The Perfect Speaker. Public Speaking in Practice], Gliwice 2009, p. 43-47. B. Blein, Sztuka prezentacji i wystapień publicznych [Art of Presentation and Public Speaking], Warsaw 2010, p. 36.

${ }^{10} \mathrm{Ch}$. Biscontin, $O$ homilię bardziej skuteczna - wyznaczyć cel homili [On a more effective homily - to set the goal for the homily], "Przegląd Homiletyczny" 2001-2002 z. 5-6, s. 54-58. 
demands of them. In addition, it will make it possible to outline the limits of the subject matter, which will protect the preacher from some of the most serious mistakes made by those who speak in public: information overload, information shortage, and chaos. The last of these errors is expressed by talking about many things at once, with digressions and repetitions that are detached from the subject of the speech, lack of logical order or links between individual sentences or words. In a persuasive speech the principle of maximum subordination of the content to the purpose of the speech should be adopted. This will undoubtedly have a positive impact both on the level of communication between the preacher of the word of God and the faithful and on the effectiveness of its proclamation. ${ }^{11}$

\section{It should be stated that each unit of preaching should be built around a single thought; the preacher has the obligation to specify the expected results.}

Also Church documents recommend that the subject of preaching should be narrowed to a given unit and clearly and precisely determine the purpose of the homily. When Pope Francis talks about the process of preparation for the proclamation of the word of God, he first calls for an appropriate reading of Sacred Scripture with its comprehension. He remarks that it is not the preacher's goal to understand all the small details of the passage he is reading, but to discover the main message. This, as the Bishop of Rome points out, involves not only learning about the idea behind the biblical author, but also about the effect he wanted to have on his readers. ${ }^{12}$ The pope proposes to the clergy as a tool in the process of preparing the homily practising of lectio divina, and he stresses that its final stage

${ }^{11}$ J. Bralczyk, Język na sprzedaż [Language for Sale], Gdańsk 2004, p. 12-13. Cf. B.E. Gronbeck, K. German, D. Ehinger, A.H. Monroe, Zasady komunikacji verbalnej [Principles of Public Speaking], Poznań 2001, p. 163. Cf. also A. Schwarz, Jak pracować nad kazaniem [How to Work on a Sermon], Warsaw 1993, p. 75.

${ }^{12}$ EG 146-147. 
is actio: which means that the word of God does stop at the stage of intellectual cognition, but leads to action. ${ }^{13}$

Considering the Church's teaching in this respect, we should not forget about the advice of Pope Benedict XVI to avoid general and abstract homilies. This corresponds to the thesis of L. Buksak that the goal of a persuasive speech cannot be equated with a dream and therefore one cannot afford unrealistic, indefinite and imprecise goals. In practice this will be expressed by the need to answer questions like "What exactly should the audience remember?" "What, when and how should they do (it)?" This opens the way for the preparation of the homily, which will be a transformative action according to the words of Saint Augustine: "if you don't make me better than I was, why are you preaching to me?"14

\section{WHO IS THE SPEAKER?}

Antonio Spadaro, editor-in-chief of La Civilta Cattolica, the oldest Italian magazine, analysing the preaching of Pope Francis, pointed out that preaching the word of God is not a recitation of religious content or a transmission of information, but the speech of a witness who makes God present and caring for his people. ${ }^{15}$ This concise statement indicates that it is extremely important to stop at the next point of the circle structure where the preacher should ask himself: "In which capacity I am going to speak?" "What is important to me in the issues on which I am speaking?" or "What content would I prefer to omit?" or "Which content I do not identify with?"

The need to answer these questions is confirmed by both the theological and communication sciences. Thanks to this, the homilist can avoid one of the most inexcusable defects, which is lack of cohesion. The listeners can very quickly sense when the speaker starts to pretend, preaching theses that are not supported by his experience or that he does not believe in. ${ }^{16}$

${ }^{13}$ DH 27.

${ }^{14}$ SC 46, L. Buksak, op. cit., p. 66, Ch. Biscontin, op. cit., p. 60.

${ }^{15}$ A. Spadaro, Mówione magisterium papieża Franciszka [Spoken magisterium of Pope Francis], in: Francis, Bóg szuka nas na marginesie. Słowa z Domy Świętej Marty [God is looking for us in the peripheries. Words from St. Martha's House], Krakow 2017, p. 14-15.

${ }^{16}$ L. Buksak, op. cit., p. 67-70. 
The speaker should always be aware that each statement contains not only information about the state of affairs, but also about him. In this context, the point is that it is the messages that reveal the speaker's attitude to the content that come to the fore. As if in an information package we send the listener an answer to the question: "Is what I say rooted in my experience, life, feeling and thinking, does it originate from me."17 If the preacher of the word of God adopts the attitude of a neutral interpreter towards the listeners, the content transmitted through him will not live and will not awaken anyone to life. That is why a preacher can only give his listeners what is really his, according to the principle: if I try to give more than I actually have, I give less. ${ }^{18}$

The above indications are a part of the broad problem of considering the unit of preaching as a testimony and the one proclaiming the word of God as a witness. ${ }^{19}$ The first postulate of the psychology of communication is not a new problem, but still demands that it be taken into account and applied in homiletics. Even objectively the best content read from a page without engagement may simply not reach the audience, who will pay attention to the attitude of the preacher to what he communicates. Research confirms that anyone who only speaks as a representative of a group receives the most critical assessment. For the listener can easily undermine his credibility by stating simply: "he says so, because he has to say so." It does not mean that the preacher will solve this problem by using the pronoun I and revealing a lot about himself: rather, he needs to talk about a specific topic in a committed way. ${ }^{20}$

In this context, it seems understandable that Pope Francis calls for the preacher to begin by preparing his homily by deepening his personal intimacy with the word of God, becoming the first hearer of what God wants to say to

${ }^{17}$ F. Schulz von Thun, Miteiander redden 1. Störungen und Klärungen Allgemeine Psychologie der Kommunikation, Hamburg 2008, p. 109. Cf. A. Załazińska, M. Rusinek, Retoryka podręczna czyli jak wnikliwie słuchać i przekonująco mówić [Handy Rhetoric, or how to listen carefully and speak convincingly], Kraków 2005, p. 9.

${ }^{18} \mathrm{~F}$. Schulz von Thun, Klarkommen mit sich selbst und anderen: Kommunikation und soziale Kompetenz. Reden, Aufsätze, Dialogues, Hamburg 2007, p. 214-215.

${ }^{19}$ For more see Fr. Müller, Predigt ist Zeugnis. Grundlegung der Homiletik, Freiburg-BaselWien 2007.

${ }^{20}$ A. Załazińska, M. Rusinek, Retoryka podręczna czyli jak wnikliwie słuchać i przekonująco mówić [Handy Rhetoric, or how to listen carefully and speak convincingly], Kraków 2005, p. 12-17. 
the community through his mouth. The Bishop of Rome reminds contemporary preachers of the word of God that Jesus of Nazareth was negative to those who passed on God's teachings to others, but did not accept them themselves, and clearly states that the homilist should communicate what he himself has contemplated. He calls on the preachers to do away with the attitude of thinking that the message from Scripture is addressed to others, rather than to the preacher himself. ${ }^{21}$

\section{ADDRESSEE OR A LISTENER-ORIENTED HOMILIST}

The authors of the General Introduction to the Roman Missal, describing what a homily is, draw attention not only to the need to clarify the sacred text, but also to take into account in this process the celebrated mystery and the special needs of the audience. ${ }^{22}$ The American Bishops went even further and, in creating a document on the proclamation of the word of God, they began their reflections with an analysis of the contemporary listener, noting that this is supported by both theological (or more precisely, ecclesiological) and psychological reasons. On the one hand, a proper understanding of the people to whom one speaks - as the Bishops of the United States have written - is a condition for effective communication. On the other hand, a correct view of the Church makes us see in her first the community of the People of God gathered by Christ. They remind us that it is "people who make up the Church" and "the Church is made up of people," so we cannot agree with a style of preaching the word of God that indicates that only the preacher has access to the truth, knows what is best for everyone and can solve any problem. ${ }^{23}$

We stop at the US bishops' document because it was the first one in which the preacher was assigned the role of mediator, suggesting a move away from explanatory and instructive preaching in favour of interpretative preaching. The homilist, according to this document, is supposed to represent the community,

${ }^{21}$ EG 149-153. Cf. DH 27.

${ }^{22}$ Congregation for Divine Worship and the Discipline of the Sacraments, General Introduction to the Roman Missal, (hereinafter: GIRM) 65; http://www.vatican.va/roman_curia/ congregations/ccdds/documents-/rc_con_ccdds_doc_20030317_ordinamento-messale_ en.html (2020).

${ }^{23}$ FIYH, p. 63-65. 
expressing its experiences and aspirations by naming its problems and joys. He is also supposed to represent God, who offers to a particular congregation a word of healing, forgiveness, acceptance and love. This viewpoint makes it the preacher's task not so much to explain the holy texts as to interpret the lives of the listeners based on the holy texts. ${ }^{24}$

In the same spirit speaks Pope Francis when he orders preachers not only to listen to the people, but even to "contemplate the people" so as to discover what the faithful need to hear, to know their desires, their riches and limitations, and how they look at the world and life. The Bishop of Rome's warning not to answer in his homily questions which nobody asks himself takes on the character of a directive in the context of our reflections. ${ }^{25}$

In practice, the audience-oriented attitude consists in analysing the audience from a demographic and psychological point of view. It is necessary to start by collecting basic information about the number of recipients, their age, sex, education and group affiliation. One speaks differently to a smaller, homogeneous group, and differently when the number of listeners is larger and they are varied. In this context, it is worth noting whether a dominant group can be distinguished by age and whether there is any relationship between listeners of different ages (e.g. parents with children). It is also important whether the audience is dominated by the speaker's peers or whether there is an age difference between them. The analysis of the listeners in terms of their education aims at figuring out the level of knowledge about the issues that will be addressed during the speech. This will allow for the selection of appropriate language, arguments and images. ${ }^{26}$

The next step is an effort to learn about the listeners' beliefs, attitudes and values. This is essential if the speaker intends to influence the audience. It is then necessary to gain an elementary knowledge of how the people to whom the speech is addressed react to certain views and what their individual preferences and judgments are, what they consider important and what is completely worthless to them. This will make it possible to anticipate the reaction of the audience to the words to be conveyed to them, to improve mutual communication,

\footnotetext{
${ }^{24}$ Ibid, p. 67-78.

${ }^{25}$ EG 154-155.

${ }^{26}$ B.E. Gronbeck et al., op. cit., p. 97-98. Cf. L. Buksak, op. cit., p. 70-71.
} 
to modify the message accordingly, so that the theses presented by the speaker will be readily accepted. ${ }^{27}$

The preacher should remember about the rule in the field of communication sciences, which says that the first condition of effectiveness is the recipient's feeling that the message is being broadcast for him. The power of persuasion is weakened by the impression that the the speech is addressed to all or a very wide group of listeners. Everyone who starts working on the homily faces a kind of paradox of "reconciling persuasive intimacy with the universality of impact." ${ }^{28}$ He should create and deliver a text that will reach the widest possible audience, but in such a way that everyone is convinced that he is the only recipient of the speech.

\section{The preacher should create and deliver a text that will reach the widest possible audience, but in such a way that everyone is convinced that he is the only recipient of the speech.}

\section{HOW WILL I BENEFIT FROM IT?}

The audience-oriented attitude is undoubtedly connected with getting to know the needs of the audience. Of course, it does not mean that the audience should only hear what it wants to hear, although knowing the needs of the audience makes it easier for speakers to give them what they should hear. Therefore, the next stop on the structure's circle directs the speaker's attention to the question which the recipients of the message are asking themselves and which is: What will I get out of it? ${ }^{29}$ As L. Buksak emphasizes, nobody wants to waste his time, so when deciding to participate in the presentation, everyone assumes that he will achieve certain benefits. The actions that the speaker expects from those who listen to him require some effort, dedication, sacrifices or greater involvement. For

\footnotetext{
${ }^{27}$ B.E. Gronbeck et al., op. cit., p. 102-111. Cf. L. Buksak, op. cit., p. 70-73.

${ }^{28}$ J. Bralczyk, op. cit., p. 20-21.

${ }^{29}$ L. Buksak, op. cit., p. 74.
} 
persuasion to be effective, the listener needs to know what benefit he will gain by following the instructions of the sender of the message. ${ }^{30}$

In this context, it seems appropriate to draw attention to three spheres to which a persuasive text may refer: the sphere of right, when the speaker presents the advantages of a certain thing, talks about its practical application and functionality; the sphere of emotion, which consists in arousing or extinguishing such feelings as pride, fear, love, shame, safety, happiness, a sense of prestige; and the sphere of norms, when the speaker shows the relationship between a particular behaviour and commonly accepted custom, moral norms or ethical principles. ${ }^{31}$ Speaking, therefore, it is necessary to "move" within these three spheres, presenting to the audience in an appropriate way the benefits they will gain by responding positively to the call made in the communication.

Given that during a presentation, language is the most natural tool of persuasion, the speaker needs to discern the difference between the language of description and the language of benefit. A speaker using descriptive language during a presentation will only draw attention to the features or advantages of the subject matter of his speech. If it is a car, for example, he will describe safety systems. The language of benefits, on the other hand, draws attention to how a given feature translates into the specific life of the listener. Using the same example, the above-mentioned safety systems will ensure that their owner will safely take the family to their destination. ${ }^{32}$

Applying the above considerations to homiletics one can get the impression that contemporary preachers have no problem with describing Christianity, passing on information about God and the principles of life that should be led by a baptized person. They have a huge problem in expressing these "qualities" in the language of benefit. Hence the questions - "how do the listeners benefit from observing the norms of Christian life or getting to know God more closely?" or "how will practicing the commandment of love or the eight blessings positively affect their lives?" - cannot be ignored when preparing the unit of preaching. These three natural spheres should provide the answers.

\footnotetext{
${ }^{30}$ Ibid., 74-75.

${ }^{31}$ J. Bralczyk, op. cit., p. 18.

${ }^{32}$ A. Rzędowska and J. Rzędowski, op. cit., p. 75-76.
} 


\section{MESSAGE, OR WHAT SHOULD I SAY?}

In defining the homily, the General Instruction of the Roman Missal stresses that it should be "exposition of some aspect of the readings from Sacred Scripture or of another text from the Ordinary or from the Proper of the Mass of the day." ${ }^{33}$ In the context of these considerations the term "aspect" should be noted. It allows us to say that in the process of preaching the word of God it is a mistake to try to discuss in one unit of preaching all the themes that emerge from the liturgy of the word of the day. As a result, it is undesirable to discuss individual Bible readings in a homily in isolation, without trying to establish the connecting content or the intentions of the creators of the text. Rather, it should be assumed that it is not possible to convey all the content of the Gospel in a single speech, and each unit of preaching needs to be continued and completed. ${ }^{34}$

This corresponds to the last stop on the structure's circle, which - according to L. Buksak - should be accompanied by the principle that public speaking is the art of resignation, i.e. the choice of what is necessary and most important. ${ }^{35}$ In the same spirit Pope Francis teaches, warning against situations in which the "homily is too long," giving the impression that the listener is attending a conference or lesson. ${ }^{36}$ Therefore, the effectiveness of the homily can be favourably influenced by several elementary principles of creating a message according to the formula five-point. For obvious reasons, we will not focus on the content of the homily itself, since it is strictly defined and written in the Church's documents. ${ }^{37}$ Instead, taking into account the previous stops of the five-milestone formula, we will pay attention to how to prepare the essential part of the preaching unit.

The first step is the so-called "brainstorming", during which the preacher writes down on sheets of paper in the form of slogans, key words and associations, everything connected with the subject, bearing in mind the aforementioned principle of maximum subordination of the content to the goal of the statement. He should focus on the factual information he will want to convey, the arguments he intends to evoke and associations connected with the subject, i.e. events, quotations, pictures, films or names of people whose life stories may constitute an

${ }^{35}$ L. Buksak, op. cit., p. 76-78. 
element of his statement. ${ }^{38}$ Next, the collected material should be properly arranged, with individual issues and slogans being assigned to different categories.

Taking into account the principle that the listener is able to remember up to three elements of a statement, at this stage it is necessary to select and determine which groups are necessary to achieve the goal. This will result in a decision to choose the three most important points of the homily, overlapping with the three category titles considered as key. After arranging them in the order that seems the most logical, the speaker starts working with each category separately and selects the material in each of them, aiming to leave only the three most important slogans or keywords according to him. These will be the sub-points for each category. In this way, he will create the core, i.e. the substantive content of the speech, consisting of three points, each of which contains three sub-points. ${ }^{39}$

At a later stage in the preparation of the homily, the possibility of modifying the content should not be excluded. For, given that the preacher is supposed to teach "not his wisdom, but the word of God," the results of the above-mentioned works should be verified, ${ }^{40}$ taking into account first of all the principles of interpretation of Scripture, Tradition and teaching of the Church's Magisterium. In practice, this will mean the need to compare the results obtained in the five-milestone formula process with the biblical comments, the teaching of the Fathers of the Church, the documents of the Holy See and the theological literature.

\section{CONCLUSIONS}

The use of the principles of rhetoric and theory of communication and the incorporation of the achievements of psychological sciences in the work of evangelization is not a new problem. St. Augustine, among others, drew attention to it when he wrote: "Now, the art of rhetoric being available for the enforcing either of truth or falsehood, who will dare to say that truth in the person of its defenders is to take its stand unarmed against falsehood? For example, that those who are trying to persuade men of what is false are to know how to introduce their subject, so as to put the hearer into a friendly, or attentive, or teachable frame of mind,

\footnotetext{
${ }^{38}$ L. Buksak, op. cit., p. 79-80.

${ }^{39}$ Ibid, p. 80-82.

${ }^{40}$ Second Vatican Council, Decree on the Ministry and Life of Priests 4.
} 
while the defenders of the truth shall be ignorant of that art? That the former are to tell their falsehoods briefly, clearly, and plausibly, while the latter shall tell the truth in such a way that it is tedious to listen to, hard to understand, and, in fine, not easy to believe it? That the former are to oppose the to melt, to enliven, and to rouse them, while the latter shall in defence of the truth be sluggish, and frigid, and somnolent? Who is such a fool as to think this wisdom?"41

There is no doubt that the five-milestone formula was not created to support the teaching task of the Church. However, given that it is successfully applied in the preparation of persuasive speeches, it also deserves attention in the process of preparing homilies, sermons or catechesis. Without denying anything that constitutes the nature of the units of preaching and their supreme subject, which is God, speaking to the faithful, the preacher should use all the means at his disposal to make his preaching pleasant to listen to, easy to understand, so as to draw his listeners to live the word of God. In this context, it should be stated that using the discussed formula, taking into account the modifications resulting from what homily is, may positively affect the quality of preaching, which only confirms the thesis concerning the need to use methods improving the preparation process and the effectiveness of persuasion speeches in the ministry of the word of God as well as the positive results of education in the field of communication sciences of theology students preparing to evangelize.

\section{REFERENCES}

Augustine, De doctrina Christiana - O nauce chrześcijańskiej [De doctrina Christiana. About the Christian teachings], Warsaw 1989.

Benedict XVI, Post-synodal Apostolic Exhortation Sacramentum Caritatis, http://www. vatican.va/content/benedict-xvi/en/apost_exhortations/documents/-hf_ben-xvi_ exh_20070222_sacramentum-caritatis.html (2020).

Biscontin Ch., O homilię bardziej skutecznq - wyznaczyć cel homilii [On a more effective homily - to set the goal for the homily], "Przegląd Homiletyczny" 5-6 (2001-2002), p. 53-60.

Bishops' Committee on Priestly Life and Ministry, United States Conference of Catholic Bishops, Fulfilled in Your Hearing. The Homily in the Sunday Assembly, http://www.

${ }^{41}$ Augustine, De doctrina Christiana - O nauce chrześcijańskiej [De doctrina Christiana. On Christian Teaching], Warsaw 1989, p. 182-183; English text available at: https://faculty. georgetown.edu/jod/augustine/ddc4.html (2020). 
usccb.org/beliefs-and-teachings/vocations/priesthood/priestly-life-and-ministry/ upload/fiyh.pdf (2020).

Blein B., Sztuka prezentacji i wystąień publicznych [Art of Presentation and Public Speaking], Warsaw 2010.

Broński W., Język i zachowania niewerbalne kaznodziei w służbie nowej ewangelizacji [The language and non-verbal behaviours of preachers at the service of the new evangelization], "Przegląd Homiletyczny" 9 (2005), p. 123-132.

Bralczyk J., Język na sprzedaż [Language for sale], Gdańsk 2004.

Buksak L., Szkoła mówców. Myśl i prezentuj inaczej niż wszyscy [School for Orators. Think and Present Differently than Everyone Else], Gliwice 2019.

Codex Iuris Canonici, Poznan 1984.

Congregation for Divine Worship and the Discipline of the Sacraments, Homiletic Directory, https://www.vatican.va/roman_curia/congregations/ccdds/documents/rc_ con_ccdds_doc_20140629_direttorio-omiletico_en.html (2020).

Congregation for the Clergy, General Directory for Catechesis, https://www.vatican.va/roman_curia/congregations/cclergy/documents/rc_con_ccatheduc_doc_17041998_ directory-for-catechesis_en.html (2020).

Congregation for the Clergy, The Priest, Pastor and Leader of the Parish Community http:// www.vatican.va/roman_curia/congregations/cclergy/documents/rc_con_cclergy_ doc_20020804_istruzione-presbitero_en.html (2020).

Congregation for Divine Worship and Discipline of the Sacraments, General Introduction to the Roman Missal, http://www.vatican.va/roman_curia/congregations/ccdds/documents-/rc_con_ccdds_doc_20030317_ordinamento-messale_en.html (2020).

Dyk S., Atrakcyjny sposób przepowiadania homilijnego [Attractive way of homily preaching], in: H. Słotwińska (ed.), W służbie Bogu i ludziom. Księga pamiq̨tkowa poświęcona ks. prof. dr. hab. Władysławowi Głowie z okazji 65-lecia urodzin i 40-lecia kapłaństwa [In service to God and people. Memorial Book dedicated to Rev. Prof. Władysław Głowa on the occasion of his 65th birthday and 40th anniversary of the priesthood], Lublin 2005, p. 133-142.

Francis, Apostolic Exhortation Evangelii Gaudium. On the proclamation of the Gospel in today's world, http://www.vatican.va/content/francesco/en/apost_exhortations/ docu-ments/papa-francesco_esortazione-ap_20131124_evangelii-gaudium.html (2020).

Gronbeck B.E., German K., Ehinger D., Monroe A.H., Zasady komunikacji verbalnej [Principles of Public Speaking], Poznan 2001.

Müller P., Predigt ist Zeugnis. Grundlegung der Homiletik, Freiburg-Basel-Vienna 2007.

Panuś K., Sztuka głoszenia kazań [The art of preaching], Kraków 2008.

Paul VI, Encyclical Ecclesiam suam, Wrocław 2006.

Rusinek M., Załazinska A., Retoryka podręczna czyli jak wnikliwie słuchać i przekonująco mówić [Handy Rhetoric, or how to listen carefully and speak convincingly], Krakow 2005. 
Rzędowska A., Rzędowski J., Mówca doskonały. Wystąpienia publiczne w praktyce [The Perfect Speaker. Public Speaking in Practice], Gliwice 2009.

Sacred Congregation of Rites. Inter Oecumenici Instruction on Implementing the Constitution on Sacred Liturgy, https://www.ewtn.com/catholicism/library/inter-oecumenici--instruction-on-implementing-the-constitution-on-sacred-liturgy-2182 (2020).

Schulz von Thun F., Klarkommen mit sich selbst und anderen: Kommunikation und soziale Kompetenz. Reden, Aufsätze, Dialoge, Hamburg 2007.

Schulz von Thun F., Miteiander redden 1. Störungen und Klärungen Allgemeine Psychologie der Kommunikation, Hamburg 2008.

Schwarz A., Jak pracować nad kazaniem [How to Work on a Sermon], Warsaw 1993.

Second Vatican Council, Decree on the Ministry and Life of Priests, http://www.vatican.va/ archive/hist_councils/ii_vatican_council/documents/vat-ii_decree_19651207_presbyterorum-ordinis_en.html (2020).

Second Vatican Council, Pastoral Constitution on the Church in the Modern World, http:// www.vatican.va/archive/hist_councils/ii_vatican_council/documents/vat-ii_ cons_19651207_gaudium-et-spes_en.html (2020).

Second Vatican Council, Constitution on the Sacred Liturgy, https://www.vatican.va/archive/hist_councils/ii_vatican_council/documents/vat-ii_const_19631204_sacrosanctum-concilium_en.html (2020).

Spadaro A., Mówione magisterium papieża Franciszka [Spoken magisterium of Pope Francis], in: Francis, Bóg szuka nas na marginesie. Słowa z Domy Świętej Marty [God is looking for us in the peripheries. Words from St. Martha's House], Krakow 2017 p. 11-32.

\section{Biogram}

Rafał Kowalski, presbyter of the Archdiocese of Wrocław, doctor of theology of the Catholic University of Lublin (pastoral theology in the field of homiletics), assistant professor at the Department of Religious Communication of the Institute of Social Sciences of the Pontifical Faculty of Theology in Wrocław. Lecturer in homiletics and communication theory, Director of the Department of Social Communication of the Wroclaw Metropolitan Curia, spokesman for the Archdiocese of Wrocław.

ORCID: 0000-0002-1062-1762 